\title{
Kryzys narracji w nowoczesnej polityce Zachodu
}

\section{The Crisis of Narrative in Modern Western Policy}

\begin{abstract}
Presented article discusses the subject of the modernising practices' crisis, which arises at the foundations of political order. This crisis is systemic - it refers not only to capitalism and economic management but to their deviation in the form of neoliberalism that turns out as speculative ground of explanation for mainstream economy. Western economic thought has led in consequence to the virtualization of the economy, which in the virtual trading economy, qualities that do not exist - it generates profits in the form of money created by the banks in the mechanism of money creation of deposits. This is probably the greatest evil that now contributes to the crisis of the West.
\end{abstract}

Keywords: crisis, mainstream economy, promoting western values, free market, privatisation, transnational corporations

Wszystkie projekty modernizacji mają wspólną świadomość rozdźwięku pomiędzy obietnicami i realnymi, społecznymi procesami postępu. Tak jak wcześniejsze utopie przywoływały obietnicę powszechnej emancypacji, wyzwolenia ludzkości z wszelkich ograniczeń związanych z tradycjami i normami moralnymi, współczesność w centrum uwagi stawia pojedynczego człowieka, a w miejsce powszechnej szczęśliwości dla wszystkich obiecuje każdej jednostce osiągnięcie prywatnego szczęścia. Należy sądzić, że nowoczesność - rozumiana jako szczególne doświadczenie czasu i jako zespół zmian zachodzących na świecie - jest powiązana z praktyką nieuchronnej utraty ${ }^{1}$. Pochodzenie słowa „nowoczesność" z łacińskiego modernus, oznaczającego „teraz” lub „dziš"

Nowoczesność to okres europejskiej kultury Zachodu, który zaczął się w renesansie po „odczarowaniu świata" $\mathrm{z}$ władzy mitu i religii, swoje apogeum osiągnął w oświeceniu i w dziewiętnastowiecznym scjentyzmie, a następnie uległ wojnom, rewolucjom, systemom totalitarnym, globalizacji, aby w końcowej fazie wykreować siłę sprawczą wszechwładzy ekonomicznej. Życie polityczne, wszędzie tam gdzie jest nowoczesne, nieustannie unieważnia własne wzorce twierdzi Hannah Arendt (2007, s. 72). 
w opozycji do „wczoraj”, determinuje wątpliwe poczucie przeszłości i tego, że przeszłość bezpowrotnie przeminęła. Bez wątpienia może się okazać, że znaki nowoczesności sygnalizują jedynie impuls do zaznaczenia różnicy między chwilą obecną a przeszłością, do dostrzeżenia specyfiki i odmienności momentu historycznego. Kategorie nowoczesności zwykło się traktować jako nową świadomość czasu, zorientowaną nie na powtarzanie cyklu zmian społecznych, ale na doczesność linearną, sekwencyjną i nieodwracalną, przeliczaną potęgą postępu i powszechnego dobrobytu ${ }^{2}$. W odniesieniu do każdego możliwego rozumienia modernizmu w każdym podsystemie społecznym powinniśmy być w stanie zadać pytanie o istotne aspekty nowoczesności. Także o to, które spośród obietnic nowoczesności są wciąż uznawane za możliwe do spełnienia. Założenie, że niczym nieskrępowany kapitalizm za każdym razem prowadzi do dobrych rezultatów, okazało się iluzją pozbawioną racjonalnego krytycyzmu i racjonalizującego wpływu doświadczenia.

W konsekwencji wielkich przemian, które w dużej części są nieodwracalne, można mówić o nadejściu okresu geopolitycznej płynności i niepewności świata policentrycznego, gdzie będzie kilka ośrodków siły w miejsce jednego ${ }^{3}$. Ów świat jest jak multipleksowe kino, które daje widzom wybór różnych filmów, aktorów, reżyserów pod jednym dachem. Scena świata, jaki znamy z opowieści Zachodu ostatnich dekad - to parada światowych, zderegulowanych i przekraczających wszelkie polityczne i społeczne bariery rynków, na czele z rynkami finansowymi, należącymi do twardego jądra światowej struktury dominacji. Często nie dostrzega się, że procesy konstruowania obrazu świata są uwikłane w walkę o dominację, zatem wszystko, co polityczne, jest dziełem ludzkim, a nie wynikiem aktu kreacji, nie jest określone raz na zawsze. Wiedza społeczna w odróżnieniu od wiedzy przyrodniczej ma walor polityczny, co oznacza, że staje się siłą realną, jeśli zainteresuje sobą społeczeństwo. Mówiąc inaczej, same koncepcje, wizje czy teorie mają w świecie społecznym znaczenie praktyczne, zmieniają bowiem myślenie ludzi, ich intencje, a w konsekwencji ich działania. Ową polityczność dostrzegamy w przestrzeni publicznej rozpiętej pomiędzy „jakimś” projektem porządku a zakorzenioną w ludzkiej naturze niezdolnością do jego urzeczywistnienia. W tym kontekście możemy zadać pytanie:

Siły ekonomiczne zespalają świat w jedną gospodarkę, w mniejszym stopniu - w jedno społeczeństwo polityczne. Narody uczestniczą w globalnym zarządzaniu zgodnie z ich siłą ekonomiczną, która jest współmierna z ich prawami. Globalnym porządkiem rządzi nieformalny rząd najsilniejszych gospodarczo krajów świata; jego prawo jest logiką rynku, a status w tym nowym porządku jest funkcją wydajności ekonomicznej (zob. Ake, 1995).

Taki porządek jest nie wielobiegunowym, lecz wielopłaszczyznowym światem. Jest to świat wielorodzinny, gdzie liberalizm zachodni (i jego preferowane drogi rozwoju gospodarczego i zarządzania) jest tylko częścią tego, co jest w ofercie (zob. Mazarr, 2017). 
Czy paradygmat globalizacyjny w narracji Zachodu pozostaje (i czy od samego początku był) adekwatny do opisu współczesnego świata? Obok narracji wiążących doświadczenia historyczne z rozpoznawaniem dynamiki zmian zasadniczego znaczenia nabiera potrzeba podniesienia na nowo kwestii obietnic zajmujących centralne miejsce $\mathrm{w}$ wypowiedziach poprzedników, a mianowicie strukturalnego braku równowagi, sięgającego głęboko do reguł antagonizowania społecznej egzystencji ${ }^{4}$.

\section{Uwarunkowania i wektory konceptualizacji zmiany}

W koncepcjach społecznej ontologii modernistycznego społeczeństwa Zachodu rozpowszechnił się mityczny obraz samoorganizacji, ujawniający istnienie dwóch oddzielnych bodźców stymulujących proces historyczny. Pierwszy ma charakter ekonomiczny, gdzie unowocześnianie gospodarki jest procesem spójnym, i dlatego wszystkie społeczeństwa, niezależnie od kulturowego punktu wyjścia, muszą zaakceptować jego podstawowe warunki. Dominujący dyskurs publiczny stara się ukazywać rzekomo nieograniczoną swobodę wyboru oferowaną człowiekowi przez rynek, a tworzone projekty instytucjonalizacji zakładają, że współpraca ludzi owocuje optymalną dla społeczeństwa formą samoorganizacji, przybierającą postać niewidzialnej ręki rynku. Drugim bodźcem jest walka o uznanie, bo wszystkie istoty ludzkie pragną nie tylko materialnego dobrobytu. Domagają się także uznania swojej godności i statusu przez inne ludzkie istoty - i właśnie to pragnienie stanowi fundamentalną podstawę polityki. Przywołując oświeceniowe wyobrażenia ludzkiej doskonałości, powiązane $\mathrm{z}$ ideami postępu, eksponowano ideały powszechnej równości, indywidualizmu, życia na wyższym poziomie w następstwie osiągnięć z medycyny, technologii, ekonomii - innymi słowy sakralizacji postępu przez rozum. W ten sposób polityka uznania wiązała się z rozbiciem starych i łączeniem nowych, dawniej odrębnych form kulturowych, skoncentrowanych na pracy, wspólnych

\footnotetext{
Pytania o przyczyny strukturalnego braku równowagi dotyczą pojęcia konsensusu waszyngtońskiego, które zostało wprowadzone do publicznego obiegu przez Johna Williamsona z Institute for International Economics w 1989 roku. W moim rozumieniu zasady liberalizmu stanowiącego później podstawę ideologii neoliberalnej oznaczały listę szczegółowych reform politycznych, które zostały szeroko omówione w Waszyngtonie, aby były pożądane we wszystkich krajach Ameryki Łacińskiej, począwszy od roku 1989; zbiór polityk ekonomicznych zalecanych dla krajów rozwijających się przez międzynarodowe instytucje finansowe (przede wszystkim MFW i Bank Światowy). W stanowiskach krytyków instytucje finansowe stają się agentami neoliberalizmu, a zatem dążą do zminimalizowania roli państwa (zob. Williamson, 2004).
} 
zainteresowań sztuki, etniczności, tożsamości płciowej oraz innych dystynkcji kulturowych nowoczesności ${ }^{5}$.

Utopijny element projektu nowoczesności odegrał istotną rolę w większości transformacji politycznych XX wieku, został również wykorzystany w retoryce związanej z ogromnym wsparciem przez państwo globalizacji kapitału, często nazywanym „modernizacją" Tego rodzaju praktyki odnajdziemy nie tylko $\mathrm{w}$ polityce, prawie i w stosunkach międzynarodowych, ale również w ekonomii czy technologii. Fundamentalnym warunkiem aplikowanego projektu stało się przekonanie, że najlepszym sposobem zwiększania wzrostu gospodarczego powinno być pełne uczestnictwo danego kraju w wolnym kapitalistycznym handlu i przestrzeganie zasad lokowania kapitałuํ. To oznaczało, że kraje będą się rozwijać szybciej, jeśli obniży się bariery celne, zaprzestanie się subwencji, sprywatyzuje się przemysł państwowy, otworzy wewnętrzne rynki kapitałowe dla napływających z zewnątrz pieniędzy. Wszystkie wymienione czynniki miały stanowić drogę do podnoszenia bogactwa i zamożności wszystkich ludzi.

Opowieść o nowoczesności Zachodu w ostatnich dekadach można dostrzec w trzech domenach: (1) w strefie pomnażania zasobów informacji, gdzie informacja przestała być dobrem rzadkim i stała się dobrem nadmiernej obfitości; (2) w strefie społeczeństwa informacyjnego, dla którego tworzenie, dyfuzja i absorpcja informacji stały się fundamentem funkcjonowania tego społeczeństwa; (3) w obszarze dotyczącym rozwoju gospodarki opartej na wiedzy, gdzie przyjęto założenie, że gospodarka, która zinternalizowała wiedzę, stanowi decydujący endogenny czynnik rozwoju. We wszystkich tych obszarach podkreślano znaczenie konkurencyjności opartej na wykwalifikowanej i wartościowej sile roboczej, współpracy ośrodków naukowych ze światem biznesu, budowie dobrobytu $\mathrm{z}$ wykorzystaniem systemu wolnorynkowego oraz działań skupionych na optymalizacji dochodu. Paradoksem powstania gospodarki informacyjnej jest

Wiara w ustrojową modernizację stanowiła odmianę wiary w postęp, gwaranta sensu historii zastępującego w świeckich kulturach Zachodu ideę opatrzności. Według obowiązującego szyldu nowoczesne państwa ewoluują w kierunku liberalnej demokracji, a jeśli nie podejmują takich kroków, to znaczy, że coś im takie działania uniemożliwia (zob. Golinowski, 2017, s. 169-199).

6 Zrozumienie współczesnego świata - lepiej niż, jak się wydaje, robi się to teraz - jest nie tylko ważne intelektualnie, jest również strategicznie konieczne. Dla niektórych rzeczywiście Stany Zjednoczone stały się największą potęgą w historii, z jedną bardzo oczywistą cechą odróżniającą: w odróżnieniu od swoich wielkich poprzedników - od Rzymian do Brytyjczyków - ta potęga nigdy nie upadła (Cox, 2012, s. 369-388).

7 Michael Jacobs i Mariana Mazzucato sugerują, że żaden z tych problemów prawdopodobnie nie zostanie rozwiązany przez obecne podejście do polityki gospodarczej w żadnym kraju rozwiniętym. Zachodni kapitalizm nie jest bezpowrotnie stracony, ale trzeba to przemyśleć, bo ortodoksyjna teoria ekonomiczna, która leży u podstaw większości bieżących pomysłów polityki, nie zapewnia właściwego zrozumienia, jak działa współczesny kapitalizm (zob. Jacobs, Mazzucato, 2016, s. 8). 
fakt, że technologie, które teoretycznie mogłyby rozpraszać i decentralizować procesy rozwojowe w przestrzeni globalnej, prowadzą do jeszcze większej ich koncentracji (Toporowski, 2012). Innymi słowy współczesny mit nowoczesności zespolił się w bezmyślnych aktach rytualnej mantry; gospodarkę opartą na wiedzy zamieniono na gospodarkę opartą na marketingu. Rynki obiecywały lot na księżyc, a ostatecznie okazało się, że było to tylko odbicie księżyca w sadzawce. Myślenie ekonomiczne dało nam niewystarczające zasoby, które pozwalają stawić czoła wielorakim kryzysom, przed jakimi stoją współczesne gospodarki i społeczeństwa ${ }^{8}$. Aby poradzić sobie z tymi kryzysami, potrzebujemy dużo lepszego zrozumienia, jak działa współczesny kapitalizm.

Transformację instytucjonalną społeczeństw Zachodu należy więc traktować jako wielki proces, który sięga do wszystkich podsystemów społecznych. W procesie tym szczególną rolę trzeba przypisać systemowi politycznemu, a o jego powodzeniu będą decydować jakościowe zmiany w systemie ekonomicznym. Równolegle $\mathrm{z}$ tymi zmianami będą podążały zmiany w strukturze społecznej, petryfikujące nowe zależności bądź wymuszające zwolnienie tempa. Mogą one również wywoływać impulsy zmierzające do restauracji starych rozwiązań. Ostatecznie proces ten będzie zakończony dopiero wtedy, gdy zostanie odwzorowany w świadomości społecznej, to znaczy wówczas, gdy wyrosłe na bazie nowej jakości systemu społecznego wartości zostaną przyswojone przez znaczące grupy i warstwy społeczne'. Przy czym proces rekonstrukcji ładu może przebiegać przez:

- jednostronną adaptację, czyli całkowitą akceptację napływających rozwiązań instytucjonalnych, wzorów i wartości, stanowiących przejaw symbolicznej inwazji Zachodu, groźnej dla rdzenia dotychczasowej cywilizacji niezachodniej;

- adaptację selektywną, objawiającą się dualizmem społeczno-kulturowym, czyli współwystępowaniem starego układu z nowym, przy słabych

Nieprawdziwe jest stwierdzenie, że globalizacja się skończyła. W złożonym świecie globalizacja przyjmie (i już przyjmuje) inną formę. Globalizacja może się stać w mniejszym stopniu motorem napędowym handlu, a w większym stopniu bodźcem - z powodu problemów rozwojowych. Może to dać więcej miejsca inicjatywom wschodzących mocarstw, które koncentrują się bardziej na infrastrukturze niż na wolnym handlu. Współczesne poszukiwanie porządku światowego będzie wymagać spójnej strategii, aby zdefiniować pojęcie porządku w różnych regionach i powiązać je z regionalnymi oczekiwaniami wspólnot (zob. Kissinger, 2014).

9 Liberalizacja rynku miała zwiększać współzależność gospodarczą, która utrudniałaby powstawanie i rozwój konfliktów. Możliwość pojawienia się nihilizmu - powiada John Gray - jest formą odreagowania na zmarginalizowanie znaczenia religii w życiu społecznym przez oświecenie z jednej strony, i rzeczywistą autodestrukcję samego projektu oświeceniowego - z drugiej. Gray przekonuje, że kiedy dochodzi do upadku tych fundamentalizmów - religijnego i oświeceniowego - erupcja nihilizmu będzie zapewne większa niż kiedykolwiek wcześniej (zob. Gray, 2001, s. 258-260). 
efektach dyfuzyjnych i nieznacznym poziomie przenikania się kultur, co w dłuższej perspektywie grozi rozdarciem społeczeństw w kwestii drogi rozwoju;

- adaptację konwergentną, stanowiącą fuzję elementów i rozwiązań instytucjonalnych zastanych z elementami cywilizacji napływającej szerokim strumieniem z zewnątrz; w tym wypadku nie dochodzi ani do akceptacji, ani do odrzucenia, lecz następuje hybrydyzacja;

- odrzucenie napływających rozwiązań instytucjonalnych i kulturowych.

Zasady określające granice polityczności w zachodniej narracji, warunki w niej uczestnictwa, a także zasada legitymizacji i reprezentacji, jako najbardziej istotna kwestia polityczna, stały się granicami nie tylko wyznaczającymi porządek wewnętrzny państw narodowych, ale miały także - poprzez odniesienie do pozostałych - regulować relacje z innymi społeczeństwami. Doszło do osobliwego momentu, że modele ekonomiczny i polityczny Zachodu były traktowane jako kryteria oceny wszystkich innych kultur i modeli ustrojowych ${ }^{10}$. To, co nazywamy współczesnym kapitalizmem, odwołującym się do roztropności elastycznego rynku, nie jest produktem ekonomicznego procesu i nie może być wyprowadzane $\mathrm{z}$ samej logiki kapitału. Punktem wyjścia była idea społecznego rynku ekonomicznego, a zatem rynku, który nieustannie był wzmacniany i wspierany regulacjami polityczno-prawnymi oraz działaniami społecznymi mającymi w zamierzeniu rozwinąć instytucje opiekuńcze. Tym samym oparty na rachunku ekonomicznym schemat doboru odpowiednich środków do celu, jakim była maksymalizacja zysku, stał się najważniejszą siłą kolonizacji świata.

Przebudowa ustroju kapitalistycznego $\mathrm{w}$ drodze modyfikacji państwa i reformowania rynków finansowych następowała stopniowo i była realizowana w wyniku oparcia polityki gospodarczej na wizji Hayeka-Friedmana, przywołującej teorię racjonalnego wyboru, a zwłaszcza jej neoklasyczne rozumienie $\mathrm{w}$ duchu teorii wyboru publicznego i teorii wyboru społecznego. Wspomniane koncepcje wspierały silnie związaną z nią doktrynę polityczną zwaną neoliberalizmem, który był oparty na racjonalnym wyborze. Epoka nadziei społeczności Zachodu z lat 1991-2008 była zależna od zestawu idei, który można nazwać liberalnym internacjonalizmem. Sposób myślenia na temat funkcjonowania społeczno-gospodarczego rozwiniętych krajów był kształtowany przez scharakteryzowane poniżej trzy kluczowe przekonania:

10 Gdyby przyjąć literalną realizację ideałów neoliberalizmu, zgodnych z wizją stworzoną przez jego teoretyków (Friedricha Hayeka, Miltona Friedmana i innych), oznaczałaby ona nieustanne dążenie do niemalże całkowitego zaniku struktur państwowych, aby umożliwić nieograniczone oddziaływanie sił rynkowych (zob. Golinowski, 2016, s. 318-341). 
(1) Podstawowe strukturalne siły dojrzały i przekształciły się w zrozumiałe, transparentne, oczywiste i stopniowe czynniki zmian. Wizja świata jako jednolitego systemu gospodarczego posiadała wewnętrzną dynamikę rozwoju, a wolny rynek miał być podstawowym mechanizmem rozdziału bogactwa. Wyrazem takiego poglądu może być stanowisko mówiące o tym, że rynki są wydajne, prywatyzacja, zniesienie regulacji oraz otwarte rynki kapitałowe sprzyjają rozwojowi ekonomicznemu, a rządy powinny równoważyć budżety i zwalczać inflację. Pod wpływem postępu technologicznego został zaakceptowany prymat liberalnych rynków jako podstawowy wymóg biznesu, a społeczne skutki wydajności gospodarczej miały być minimalizowane przez powszechną edukację i doskonalenie zawodowe - czyli lepsze dopasowanie się do istniejących wyzwań rynku ${ }^{11}$. Realizacja postulatów prowadziła do utraty przez państwo instrumentów kontrolnych i wzrostu znaczenia międzynarodowych korporacji. To również okres rozwoju komputerów osobistych i internetu, a więc priorytetową ideą było przekonanie o transformującej mocy technologii, mającej być siłą przybliżającą nas do prosperity - demokracji i globalizacji.

(2) Instytucje zachodnie są bardzo stabilne i dobrze funkcjonujące, co oznaczało klamrę spinającą projekt łączący instrumenty ekspansji - zarówno polityczne, jak i militarne, edukacyjne oraz technologiczne. Społeczność Zachodu była w stanie akumulować wytwarzane nadwyżki i wykorzystywać je w celach innowacyjnych, by uzyskać przewagę nad innymi. Ekspansja Zachodu z biegiem czasu nabierała jednak coraz więcej właściwości ideologicznych mających czynić kapitalizm - według deklarowanych przez jej twórców zamierzeń - ustrojem bardziej liberalnym i demokratycznym, aby jednostki miały coraz więcej wolności, a przedsiębiorstwa coraz mniej ograniczeń krępujących je w korzystaniu ze swobód wolnorynkowych. Polityka państwa wobec firm, a zwłaszcza działalności banków i instytucji rynkowych, spotykała się nie tylko z aprobatą Wall Street, ale też z wyraźną akceptacją elit rządzących. Społeczności państw Zachodu napawały się zwycięstwem demokracji i kapitalizmu nad komunizmem, promowano amerykański model rozwoju, odzwierciedlony $\mathrm{w}$ rewolucji internetowej i neoliberalnej wizji gospodarki, dynamizowano procesy integracyjne w Europie, rozniecano nadzieje na demokratyzację Rosji, składano deklaracje na temat zbudowania nowego ładu międzynarodowego. Jednocześnie sam

11 Historia potwierdza, że czas odrzucić analizy zapoczątkowane przez Monteskiusza, który twierdził, że tylko handel pozwoli uniknąć konfliktów. Tę bezkrytyczną wiarę podziela dziś większość ekonomistów. Gray podkreśla, że rynki to nie maszyny, które raz wprawione w ruch, działają po wieki. Są instytucjami, które przejawiają wszystkie wady swoich twórców i konflikty pomiędzy nimi. Nie tylko są podatne na cykle koniunkturalne, lecz również odzwierciedlają sprzeczne cele i wartości tych, którzy z tych rynków korzystają. Ponad wszystko systemy rynkowe są nie bardziej trwałe niż władza, na której się opierają (zob. Gray, 2014, s. 9-22). 
upadek muru berlińskiego charakteryzował nie tylko zjednoczenie Niemiec i rozpad bloku wschodniego, ale także reintegrację kontynentu europejskiego i koniec bipolarnego świata (tutaj era postzimnowojenna wydawała się czasem błogiej transformacji) ${ }^{12}$. Innymi słowy społeczności Zachodu przyjęły postawę protekcjonalnej dominacji, restrukturyzowały gospodarkę planową, otwierając wcześniej zamknięte systemy, obejmujące byłych wrogów.

(3) Wymienione podstawy są na tyle silne, że mogą przetrwać krótkoterminowe cykle gospodarcze inspirowane zmianami politycznymi. Kombinacja liberalnego kapitalizmu i demokracji parlamentarnej wydawała się ostatecznym możliwym stadium rozwoju politycznej organizacji światowej społeczności. Stworzono przekonanie, w myśl którego w zaawansowanych gospodarkach istniała „cykliczna przestrzeń", gdzie zmiany strukturalne zachodziły bardzo wolno. W ramach koncepcji „demokratycznego pokoju” i walki o demokrację wytworzono przekonanie, że w świecie, w którym dominują wolność i kapitalizm, ryzyko konfliktu między państwami słabnie. Warto sobie uzmysłowić, że rywalizacja gospodarcza to także przemoc, a państwa świata zachodniego, czyli zasadniczo Europa i Ameryka, nie są i w dłuższej perspektywie nie mogą już być, głównym źródłem inicjatywy gospodarczej i strategicznej, jakim były jeszcze na przełomie wieków (Acharya, 2017). W tym sensie wojna i handel niczym się nie różnią, odnajdujemy tutaj te same zasady funkcjonowania - tyle że ulokowane w innym kontekście.

Państwa, które niewątpliwie są filarami procesów globalizacyjnych, promują wartości pokoju i dobrobytu na własnych prawach, poprzez subtelne formy wpływu. Jednocześnie nie tracą okazji do wkraczania w nowe domeny, a to przesądza o tym, że globalizacja modyfikuje rywalizację geopolityczną, ale jej nie eliminuje. W tym kontekście neoliberalizm ustanowił sieć relacji ekonomicznych i społecznych, które muszą prowadzić do ogromnych napięć zarówno w obrębie państw, jak i w stosunkach międzynarodowych. Zarazem unieważnił większość tradycyjnych sposobów rozładowywania konfliktów, marginalizując z definicji refleksję strategiczną. Swego rodzaju polisę ubezpieczeniową stanowiła wiara, że w ostatecznym rozrachunku amerykańska potęga militarna może pokonać każdą siłę na ziemi. W takich okolicznościach globalne korporacje mogły się stać jednymi z najpotężniejszych graczy nie tylko w sferze gospodarki, ale również polityki ${ }^{13}$. Już od początków ubiegłego wieku doktryna neoliberalna

12 O modelowym wyjaśnieniu neoliberalnej globalizacji w reakcji na zjawisko stagflacji lat 70 . XX wieku szeroko pisze Tadeusz Klementewicz, wskazując stadia przechodzenia systemu kapitalistycznego w jego płynną i elastyczną formę do czasu pojawienia się symptomów strukturalnego kryzysu w 2007 roku (zob. Klementewicz, 2013b, s. 317-348).

13 Im bardziej globalizacja jest „hiper”, tym lepiej widać jej ukryte w cieniu oblicza. Do debaty nad problemem globalnego zarządzania wraca nie tylko temat państwa, ale również ekonomia polityczna (zob. Klementewicz, 2013a). 
wykazywała określone słabości, wyraźnie nie radząc sobie ze sferą rozrastającej się do monstrualnych rozmiarów własności prywatnej, reprezentowanej przez koncerny transnarodowe. Rozważania o globalizacji politycznej jako uzupełnieniu i sposobie na ustabilizowanie globalizacji ekonomicznej dzięki „dobrym” instytucjom regulacyjnym oznaczały pewien rodzaj życzeniowego myślenia o tym, pod jakimi warunkami dałoby się owe instytucje zbudować, a także o rozmaitych aspektach ich skuteczności - nie w sensie ekonomicznym, ale w znaczeniu politycznej zdolności tych instytucji do narzucania własnych rozstrzygnięć normatywnych (por. Foster, McChesney, 2014).

\section{Instrumenty stylizowanej hegemonii Zachodu}

Kryzys finansowy, oprócz zachwiania podstawami gospodarek Zachodu, zakłócił również intelektualny dyskurs, pomagający zachodnim liderom nadawać światu sensw okresie ostatnich dekad od zakończeniazimnej wojny. Kraje wolnorynkowe weszły na ścieżkę stopniowej erozji ekonomicznej, która zakończyła się wielkim geopolitycznym krachem zachodniego systemu finansów (Altman, 2009, s. 2-14). U podłoża myślenia o nowoczesności leżały wątpliwości dotyczące procesu zmiany. Ze względu na samą dynamikę zmian ład społeczny przestał być oczywistością. Doświadczenie rozpadu, wyrażane przez alienację czy wykorzenienie, skłoniło do zadawania szeregu fundamentalnych pytań o warunki zmiany i stabilności poszczególnych społeczeństw, dynamikę wewnętrzną i zewnętrzną procesów społecznych, czy wreszcie - o możliwości kontroli procesów zmiany. Odpowiedzi na te pytania zwyczajowo tchnęły optymistyczną narracją, dawały obiecujące perspektywy na przyszłośćc ${ }^{14}$.

Można przyjąć, że istniały okresy w historii, kiedy znajdowano kompromis między pracą a kapitałem, zaś system przedstawicielski sprawnie reprezentował ekonomiczne interesy znacznej części społeczeństwa. Pierwsze dekady po II wojnie światowej były w tym zakresie zdecydowanie lepsze niż obecny okres. Większa zdolność do kompromisu pojawiła się jednak głównie ze względu na inną konfigurację wnętrza i zewnętrza systemu ${ }^{15}$. Kapitał wykazywał większą otwartość i chęć ustępstw, mając na uwadze dwie przesłanki. W pierwszym aspekcie

\footnotetext{
14 Jest to efekt w dużej mierze wynikający z obserwacji rozwoju społecznego, poprzez coraz bardziej zinstytucjonalizowane, normatywizowane i abstrakcyjne „konwencje” (zob. Wagner, 2001, s. 31-35).

15 Neoliberalizm jako ostatnie $\mathrm{z}$ wcieleń nowoczesnego kapitalizmu rozwijał się $\mathrm{w}$ trzech fazach. Pierwsza z nich to okres od przełomu wieków do wielkiego kryzysu końca lat 20. XX wieku; druga faza, okres powojenny, w którym światowa gospodarka podporządkowana była ekonomii keynesowskiej; faza trzecia - czyli neoliberalizm, wyznaczany od kryzysu lat 70., z różnymi ograniczeniami trwa do dzisiaj (zob. Duménil, Lévy, 2011).
} 
światowa gospodarka nie była jeszcze tak bardzo zdecentralizowana i przerzucona na peryferia, więc przełożenie ekonomicznej opresji na działanie polityczne było trudniejsze. Obecnie natomiast cyrkulacja relacji ekonomicznych i politycznych została rozdzielona, ujawniając równocześnie brak należnej korelacji pomiędzy rozwojem gospodarczym a wydatkami społecznymi. Pracownicy w coraz większej części znajdujący się na peryferiach nie mają możliwości wywarcia politycznego wpływu na kapitał, ponieważ nie są obywatelami krajów centralnych, których systemy polityczne i prawne dają możliwość kontrolowania kapitału. W drugim aspekcie należy zwrócić uwagę na zdecydowanie odmienną sytuację geopolityczną. Istnienie „komunizmu” było swego rodzaju straszakiem wobec kapitału. W całym okresie zimnej wojny istniał, zwłaszcza w USA, rodzaj niepisanego paktu między biznesem a zatrudnionymi: kapitał zgadzał się na ustępstwa, a pracownicy rezygnowali z konwersji na socjalistyczne rozwiązania. Tak jak w wielu przypadkach, redystrybucja i kooptacja były więc wynikiem działania presji zewnętrznej wobec systemu. W obliczu upadku upiorów komunizmu strefę biznesu można było ulokować w bezpiecznej odległości od polityki, a kapitał stał się zdecydowanie mniej uległy.

W tym kontekście należy stwierdzić, że obecna koncepcja racjonalnej idei regulatywnej w narracji Zachodu, która jak nigdy dotąd osiągnęła stadium całkowitej autonomiczności wobec innych niż własny dyskurs, przestaje obowiązywać w świecie polityki. Próbując zrozumieć konkretne polityczne decyzje, zachowania i konflikty, możemy bez większego problemu wyjaśnić ich przyczyny, motywy i uwarunkowania, ale wyniki tego rodzaju procesów wyjaśniania $\mathrm{w}$ żadnej mierze nie prowadzą do włączenia polityczności w obszar racjonalnie rekonstruowanej rzeczywistości ${ }^{16}$. Historia podpowiada, że istnieją potężne siły gospodarcze popychające nas w różnych kierunkach - w stronę większej równości albo oddalające nas od niej, a to, która zwycięży, zależy od wybranej przez nas polityki. Nierówności mogą być na tyle skrajne, a polityka tak bardzo zdominowana przez najbardziej zamożnych, że nie uda się tego zmienić - tak samo jak w Europie przed I wojną światową.

Zglobalizowany kapitał egzystuje poprzez próbę takiego zarządzania kryzysem, który niezwykle zaostrzył mechanizmy przesądzające o polaryzacyjnym charakterze akumulacji w skali światowej. Degradacja Trzeciego Świata, pogłębianie się różnic między Północą a Południem, oraz niesymetryczna liberalizacja wymiany handlowej narzucana przez WTO, to tylko niektóre kierunki ekspansji kapitału potrafiącego przejąć władzę. Z myślą o ograniczeniu szkodliwych dla rynku skutków rozwarstwienia kapitalizm stworzył niezwykle wyrafinowa-

16 Aktywizacja projektu neoliberalnego pod postacią elastycznej i dynamicznej ścieżki rozwoju znalazła odwzorowanie na płaszczyznach: geoekonomicznej, normatywno-instytucjonalnej, gospodarczej, administracyjno-technicznej i symbolicznej (zob. Golinowski, 2015, s. 87-109). 
ny system stymulujący konsumpcję - od reklamy, kreującej potężne pragnienia, radykalnie większe od realnych, wygórowanych potrzeb, po coraz bardziej wysublimowane sposoby masowego, bezbolesnego, konsumenckiego kredytu. W finansowej sferze zamożny świat Zachodu przeszedł od kłopotliwych czeków, którymi wolno było płacić tylko tyle, ile się miało na koncie, do portfeli pełnych kart kredytowych z limitami, które w zasadzie pozostawały poza kontrolą. Wspierając konkretne rozwiązania instytucjonalne i wpływając na to, jak ludzie myślą, zglobalizowany kapitał sprawia, że społeczeństwa mogą więc być wyzyskiwane, i - co absurdalne, ale i realne - jednocześnie wspierać taką sytuację.

Nawet w okresie przed kryzysem, gdy wzrost gospodarczy był relatywnie duży, poziom życia większości obywateli w krajach rozwiniętych miał wręcz symboliczny charakter wzrostu. Dysproporcje między najbogatszymi grupami a resztą spoleczeństwa wzrosły natomiast do poziomów niespotykanych od XIX wieku ${ }^{17}$. Podczas gdy liberałowie socjalni wskazują na społecznie negatywne skutki „wolnego rynku" i oczekują podjęcia stosownych socjalnych interwencji w celu nadania mu ludzkiego oblicza, odnowieni liberałowie przy ochoczej asyście konserwatystów z reguły wskazują na odstępstwa i wypaczenia gospodarki względem wolnorynkowego ideału. Takie nastawienie odbiera zainteresowanym obserwatorom, ale również po części niektórym politykom, zdolność do przeprowadzenia sensownej analizy funkcjonowania rynku i stygmatyzuje samo użycie terminu „kapitalizm” jako nieprawomocne. Reorientacja zaś publicznej debaty i politycznego działania w obrębie istniejącego obecnie światowego porządku ekonomiczno-politycznego zgodnie z liniami rzeczywistych konfliktów - jest niemożliwa (Slaughter, 2017).

Złudność dotychczasowych rozwiązań związanych z efektywnym projektem rynku odsłoniła ówczesna strategia politycznego działania, oznaczająca dyfuzję odpowiedzialności. Stając w obliczu wszelkich egzystencjalnych kwestii, interesujących obywateli, rządy państw zachodnich zepchnęły odpowiedzialność na obiektywne konieczności ponadnarodowej ekonomii. Również prywatni inwestorzy korzystający z infrastruktury wypracowanej przez społeczeństwo uchylili się przed odpowiedzialnością za społeczne konsekwencje swej działalności, manifestując bezradność i swoją niewinność. Paradoks konceptualizacji wolno-

17 Erozja klasy średniej prowadzi do przebudowy porządku społecznego, który panował w USA od II wojny światowej. Mediana dochodu amerykańskiego gospodarstwa domowego w 2011 roku wyniosła 49103 dol. Po uwzględnieniu inflacji wartość ta znalazła się na poziomie nieco niższym niż w 1989 roku i o 4 tys. dol. niższym niż w roku 2000. W latach 50. i 60. XX wieku mediana dochodów pozwalała utrzymać gospodarstwo domowe z pensji jednego członka rodziny. Zazwyczaj był to mężczyzna, a jego żona prowadziła gospodarstwo domowe i wychowywała trójkę dzieci. Dochody znajdowały się na poziomie pozwalającym na zakup skromnego domu, jednego nowego auta i drugiego nieco starszego, a także na wakacje i niewielkie oszczędności - pisze szef ośrodka Stratfor (zob. Friedman, b.d.). 
rynkowego projektu ładu polegał także na tym, że instrumentem wprowadzania zmian mających przynieść endogennie i spontanicznie wykształcający się porządek społeczno-gospodarczy miało być państwo. Jednocześnie udział państwa w gospodarce był od początku uznawany za zło konieczne, a jego rola miała się sprowadzać do regulatora reguł makroekonomicznych, które należało maksymalnie oddzielić od kontekstu politycznego ${ }^{18}$. Liberalizacja gospodarki wzmogła presję lobbystów środowisk biznesowych, namawiających do skrócenia ścieżki legislacyjnej i zawężenia grona osób dyskutujących o ekonomicznych projektach, ograniczających prawa obywatelskie na rzecz praw inwestorów i nadrzędność praw handlowych nad lokalnymi przepisami - na przykład powstanie Multilateralnego Układu Inwestycyjnego (MAI). Realistyczna obserwacja bieżących trendów i przemian w różnych przestrzeniach i skalach analizy pokazuje, że państwo nie jest wystarczająco silne, aby stawić czoła operacjom globalnego kapitału, a tym samym zapewnić skuteczne ramy dla projektów radykalnej transformacji wewnątrz współczesnego modelu rynku i przeciw niemu ${ }^{19}$. Polityka gospodarcza od czasu kryzysu nie odnosi większych sukcesów. Ortodoksyjna recepta na oszczędności fiskalne - ograniczenie wydatków publicznych w celu zmniejszenia deficytów publicznych i zadłużenia - nie przywróciła gospodarkom Zachodu sprawności, a polityka gospodarcza nie zdołała się uporać z głęboko zakorzenionymi i długotrwałymi bolączkami.

\section{Opowieść Zachodu - pomiędzy pragmatyzmem a rozczarowaniem}

Istotnym wyzwaniem podejmowanym w ostatnich latach jest integracja historii z wielością niezachodnich społeczeństw. Jej rezultatem jest odrzucanie dychotomii „Zachód i reszta”. Przyjmowana perspektywa analityczna przesłania

18 Przełom między globalną operacją kapitału a jego konkretnymi instancjami stanowi ważny punkt wyjścia do analizy współczesnych mutacji państwa. W tym momencie państwa są kluczowymi aktorami, ale daleko im do monopolu w zarządzaniu i nadzorowaniu. Są raczej zmuszone do negocjowania swojej roli z różnorodnymi agencjami i liczą się z heterogenicznymi porządkami prawnymi, protokołami logistycznymi, algorytmami finansowymi i uzgodnieniami monetarnymi, które przekraczają kontrolę dowolnego państwa. Te negocjacje i rachunki przyczyniają się również do dominacji władzy wykonawczej i administracyjnej w państwie oraz do marginalizacji jej organów przedstawicielskich (zob. Neilson, Mezzadra, 2014).

19 Kryzys i wynikająca z niego recesja mogły wstrząsnąć supremacją neoliberalizmu, ale pozostaje ona niezagrożona poważnymi alternatywami i nadal kształtuje politykę po roku 2008. W tym życiu po śmierci arcymagowie reform rynkowych w globalnych centrach władzy mogą wydawać się nieco ostrożniejsi, a ich retoryczna pycha, intelektualny żargon i technokratyczna pewność siebie zostały złagodzone, ale w przeważającej części pozostają na posterunku (zob. Centeno, Cohen, 2012, s. 317-340). 
zrozumienie większości świata z jego różnymi społecznymi strukturami, politykami i kulturami. Ponadto $\mathrm{w}$ dążeniu do refleksji teoretycznej o charakterze globalnym, a nie tylko zachodniego świata, musimy uwzględniać fakt, że istnieją różne formy nowoczesności, różni aktorzy społeczni i różne tożsamości (Charrad, 2006, s. 355-356). Polaryzacja i dysfunkcje wielu demokracji na Zachodzie są dzisiaj trudne do zakwestionowania. Globalizacja i integracja sprawiły, że działania polityki były jeszcze bardziej skomplikowane, a światowy kryzys ograniczył margines operacyjny do wdrożenia polityki naprawczej oraz bezpieczeństwa do niemal zera. Gdy neoliberalna polityka doprowadziła do narastania napięć wywołanych, między innymi przez rosnące rozwarstwienie, na scenę wkroczyli radykalni konserwatyści, wierzący, że konflikty można opanować za pomocą nasilonej kontroli, policji i surowego prawa - gdy mają charakter wewnętrzny, lub zarówno wojska i tak zwanych misji stabilizacyjnych, jak i sankcji - gdy mają charakter międzynarodowy.

Kryzys liberalnego porządku ma głębsze korzenie ze względu na długoterminowe i strukturalne zmiany w globalnej gospodarce i polityce. „Dominacja jednej wielkiej potęgi może przyczynić się do porządku w polityce światowej, w szczególnych okolicznościach, ale nie jest wystarczającym warunkiem, i nie ma powodu, aby wierzyć, że jest to konieczne" (Keohane, 1984, s. 46).

W tym sensie neutralność neoliberalnego projektu ładu, odwołującego się do dyrektyw racjonalnego i bezalternatywnego mechanizmu rozwoju jest swego rodzaju przejawem mistyfikacji i pozostaje w zasadniczej sprzeczności z jego istotą i historycznym charakterem zmian. Przejawy tych antynomii, uwidaczniających się tendencji do nachalnej indoktrynacji mającej na celu uniwersalizm, odzwierciedlają następujące wymiary:

Metapolityczny - wyznaczający nieprzekraczalne granice, a także narzucający i egzekwujący przestrzeganie reguł gry oraz zagwarantowanie kontroli nad procesami i zjawiskami o charakterze globalnym. Dotyczy on refleksji nad warunkami współdziałania różnych sił społecznych o odmiennych i przeciwstawnych orientacjach ideologicznych czy zasadach funkcjonowania społeczeństw, które zapewniają równowagę i ciągłość społeczną, służą ogółowi społeczeństw, a zarazem dają szansę obrony własnych interesów. Narracja Zachodu wykazuje w tym zakresie przejawy kapitulacji wobec strategicznych kierunków dalszego rozwoju. Kryzys w relacjach ze światem niezachodnim, brak instrumentów i siły, aby być zdolnym do zarządzania zewnętrznym otoczeniem, pokazują trwałą fragmentaryzację w globalnym zarządzaniu ${ }^{20}$. Stany Zjednoczone i kra-

20 Pekin ma wszystko, co można zyskać dzięki dalszemu handlowi i inwestycjom, i niewiele do stracenia politycznie, chyba że nie jest w stanie zapewnić wzrostu gospodarczego swoim obywatelom. Same Chiny nie są w stanie utrzymać porządku, szczególnie że są niedostatecznie repre- 
je Europy nie są już w stanie stworzyć zasad i dominować w instytucjach globalnego sprawowania rządów, tak jak to się działo w okresie po II wojnie światowej. I choć elementy starego neoliberalnego porządku przetrwają, będą musiały przyjąć nowe koncepcje i nowych aktorów, którzy nie zgadzają się na sugestie i preferencje Ameryki. Zespolenie zastanych rozwiązań instytucjonalnych z elementami kultury napływającej będzie raczej prowadzić ku hybrydyzacji rozwiązań instytucjonalnych, co oznaczałoby, że w przypadku neoliberalizmu nie dochodzi ani do akceptacji, ani do odrzucenia tego projektu ładu ${ }^{21}$.

Pomimo nadmiernych roszczeń dotyczących pozycji władzy, legitymizacji oraz globalnych aspiracji, neoliberalny porządek w dużej mierze ograniczył się do grupy aktorów o równoprawnej pozycji, skupionych na obszarze euroatlantyckim, i nie obejmował wielu dużych państw, takich jak Chiny, Indie i państwa bloku radzieckiego. Również nie zawsze, a w zasadzie bardzo często, nie miał łagodnych skutków dla swoich niezachodnich zakładników ${ }^{22}$. Aspirujące do mocarstw nowe państwa nie będą zainteresowane tym, aby całkowicie wyeliminować projekt obecnego porządku, a w rzeczywistości mogą chcieć zachować niektóre jego elementy w bliższej i dalszej perspektywie czasowej. Projekt neoliberalnego porządku może być tylko jednym $\mathrm{z}$ wielu systemów i będzie się musiał zmierzyć $\mathrm{z}$ innymi pomysłami w świecie rosnącej złożoności i wzajemnych powiązań. Ameryka i jej zachodni sojusznicy muszą zrezygnować z wyłącznych przywilejów w zamian za zaufanie i współpracę z pozostałymi. Niemożliwe staje się również jednoczesne osiągnięcie pełnej liberalizacji rynków, utrzymanie suwerenności narodowej oraz demokracji - to „globalizacyjny trylemat”, obalający mit niewidzialnej ręki rynku - podkreśla Dani Rodrik. Autor uważa, że otwarcie gospodarek może skończyć się sukcesem tylko wtedy, gdy będzie osadzone w instytucjach społecznych, prawnych i politycznych, które zapewniają im prawomocność, oraz gdy nastąpi powszechne dzielenie korzyści (Rodrik, 2011).

Geoekonomiczny - ujawniający dążenie do optymalizacji siły oraz maksymalizacji bogactwa. Stany Zjednoczone nadal posiadają, choć słabnące, instru-

zentowane w MFW i WTO pomimo rosnącej potęgi gospodarczej. Stany Zjednoczone i Europa muszą pozostać głównymi filarami globalnego ładu liberalnego, ponieważ będą nadal odpowiadać za ponad 50 procent światowego handlu i globalnych inwestycji (zob. Guillén, 2016).

21 Na przykład ruch Occupy Wall Street stał się silnym krytykiem polityki chroniącej sektor finansowy i ratowanie banków w czasie kryzysu. Jednocześnie ksenofobiczne partie we Francji, Niemczech, Holandii, Szwecji i Wielkiej Brytanii zyskały popularność. Ostatnie wyniki wyborów w Europie i Stanach Zjednoczonych pokazują, że te, raczej ekstremalne, pozycje zyskują na poparciu (zob. Janssen, 2016).

22 Błędem jest uwzględnianie globalizacji tylko przez pryzmat porozumień handlowych. Nawet jeśli globalizacja gospodarcza spowolni, technologia stworzy globalizację ekologiczną, polityczną i społeczną, która wymaga wspólnych reakcji (zob. Nye, 2017). 
menty ekspansji, zarówno polityczne, jak i militarne czy technologiczne ${ }^{23}$. Europa natomiast, poprzez wprowadzenie modelu państwa dobrobytu (welfare state) nie tylko lekkomyślnie konsumowała wytwarzane nadwyżki, podnosząc tym samym krótkofalowo stopień zamożności obywateli, ale także zadłużała się u państw należących do innych cywilizacji, stwarzając przez to instrumenty nacisku na te państwa, które mają inne, często sprzeczne interesy. Rodzi to przymus spłaty nadmiernego zadłużenia i gruntowne zmniejszenie innowacyjności państw Europy (Epstein, 2005, s. 3). Równocześnie triumfalna liberalna narracja pomija fakt, że w części niezachodniego świata tendencje etniczne i nacjonalistyczne zostały w istotny sposób wzmocnione, a nie osłabione, przez siły globalizacji. Tutaj podstaw nieusuwalnych czynników kryzysowych można upatrywać na dwóch płaszczyznach:

(a) systemowego oddziaływania luki popytowej na wzrost gospodarczy, zagrażającej recesją, czyli braku zrównoważenia możliwości konsumpcji z potencjałem produkcyjnym. Dotychczasowy projekt rynku służy najbogatszym, którzy własny interes potrafią zgrabnie opakować w retorykę dobra wspólnego i wpisać w przyświecające aktualnie rządzącym ideologie ${ }^{24}$. Potrafią ponadto zaprząc do realizacji swoich celów demokratyczny proces legislacyjny, wykorzystując jego słabości. Są w stanie podporządkować sobie polityków, przy okazji wmawiając im, że ta uległość jest korzystna dla ich wyborców. Zdolność do podporządkowywania systemu politycznego własnym interesom czyni nową oligarchię być może nawet bardziej groźną od tej klasycznej. O ile ta druga prawa po prostu nie przestrzega, o tyle pierwsza wszystko realizuje legalnie. W ten sposób rozmyta oligarchia tworzy świat, w którym zwykły obywatel próbuje wpływać na politykę co cztery lata, a zasobna w kapitał firma może de facto robić to codziennie. Celem współczesnej oligarchii, reprezentowanej przez wytwornych lobbystów, jest ograniczenie wyboru i doprowadzenie do takiej sytuacji, w której każda decyzja konsumencka będzie dla nich jakoś korzystna;

(b) antagonizmu między pracą a kapitałem, będącego przejawem i jednocześnie następstwem braku automatycznego mechanizmu, mogącego określać

23 Pomimo zmian w ciągu ostatnich 70 lat wspólnota międzynarodowa nadal opiera się na tych samych instytucjach i procesach. Powinny one zostać zreformowane, dając większy wpływ takim państwom jak Chiny i Indie, przypisując im większe prawa do głosowania, proporcjonalne do ich nowej wagi w gospodarce światowej. Instytucje, takie jak WTO, Bank Światowy i ONZ, również muszą być poddane ponownej kalibracji pod kątem ich misji i zestawów narzędzi do rozwiązywania problemów (zob. Guillén, Ontiveros, 2016).

24 Raghuram Rajan - jeden z nielicznych ekonomistów, którzy ostrzegali przed globalnym kryzysem finansowym, pokazuje, w jaki sposób indywidualne wybory, które wspólnie doprowadziły do załamania gospodarczego, dokonane przez bankierów, urzędników państwowych, stanowiły reakcję na wadliwy globalny porządek finansowy, w którym zachęty do podejmowania ryzyka stwarzają zagrożenia dla całego systemu (zob. Rajan, 2010). 
właściwe proporcje podziału dochodu. W ciągu ostatniej dekady strukturalne podwaliny zaawansowanych krajów zachodnich zaczęły się kruszyć, przez co te państwa w coraz większym stopniu upodabniały się do państw rozwijających się ze słabymi instytucjami, niedobrymi fundamentami finansowymi i gospodarczymi, płynną strukturą społeczną oraz chaotyczną polityką ${ }^{25}$. Przyjęte działania i przekonania okazały się nie tylko błędne, ale nawet niebezpieczne, szczególnie że ignorowały wzrastający poziom zadłużenia i kredytowania, co było niezbędne, aby utrzymać poczucie gospodarczej i finansowej stabilności. Nawiasem mówiąc - powierzchownej stabilności, ujawniającej wzrastającą skalę niewłaściwych inwestycji w sztuczne, a nie autentyczne, czynniki wzrostu, a także powiększanie nierówności w zakresie bogactwa i możliwości jego pomnażania, jako czynników szkodliwych nie tylko dla samych obywateli, ale również dla efektywności funkcjonowania rynku ${ }^{26}$. Niekorzystne skutki tych działań nie ograniczyły się tylko do błędnych analiz i podejmowania niewłaściwych środków gospodarczych. Patologiczne warunki gospodarcze doprowadziły do politycznej polaryzacji, co w rezultacie utrudniło zarządzanie. Jego następstwem był relatywnie niski poziom wzrostu gospodarczego pomimo szerokich działań za pomocą polityki monetarnej, ujawniający wysoki poziom bezrobocia lub zatrudnienia poniżej kwalifikacji i oczekiwań.

Instytucjonalny - ukazujący zewnętrzną bezradność instytucji państwa oraz organizacji ponadnarodowych wobec korporacji międzynarodowych. Polityka poddana regułom neoliberalnej globalizacji oznaczała projektowanie „od ogółu do szczegółu”. Najpierw powstała wizja całościowa, do której musiały się dostosowywać poszczególne kraje, regiony, miejscowości i w końcu sami obywatele w projektach dotyczących swego życia. Doskonałym ucieleśnieniem tego stylu myślenia byli ekonomiści i analitycy z Banku Światowego, Międzynarodowego Funduszu Walutowego (MFW) i Światowej Organizacji Handlu (WTO), narzucający ekonomiczną, techniczną i kulturową ekspertyzę reszcie świata. Jeżeli nie uporamy się z mitem samoregulującego rynku, będziemy wywoływali coraz większe kryzysy. W obliczu równoległej egzystencji pozornie egalitarnej formy państwa $z$ promowanym przez nią systemem gospodarczym neoliberalizm usamodzielnił się w stopniu niebezpiecznie zagrażającym samej demokracji liberalnej. Zawłaszczył sferę polityki na poziomie wykluczającym realny wpływ obywateli na losy ich kraju, coraz częściej bowiem o kondycji

25 Sfera finansowa przyczyniła się do niekontrolowanego wzrostu, dynamizowanego boomem inwestycyjnym, a kredytodawcy i kredytobiorcy byli powiązani wielowątkowymi, patologicznymi zależnościami (zob. Roubini, Mihm, 2011, s. 64-72).

26 Brink Lindsey i Steven Teles twierdzą, że wielki biznes specjalnie wykorzystywał błędne przepisy rządowe, aby skierować coraz większą część bogactwa i dochodu do siebie, jednocześnie okradając gospodarkę z jej przedsiębiorczego dynamizmu (zob. Lindsey, Teles, 2017). 
gospodarki decydują czynniki pozapolityczne. Procesy globalizacji dają ogromne korzyści, ale mają również skutki uboczne. Jednym $\mathrm{z}$ nich jest powiększanie różnic dochodowych, a to szkodzi zarówno gospodarce, jak i funkcjonowaniu społeczeństw.

Nieobecność stosownej korelacji pomiędzy rozwojem gospodarczym a wydatkami socjalnymi, wyciszanie zasady pomocniczości, problemy migracyjne, wykluczenie społeczne, mała efektywność generowania dochodów ludności, zmniejszenie poziomu oszczędności - to zagadnienia, które trudno jest poddać narzędziom regulacji rynku. Procedury polityczne państwa narodowego nie nadążają za rozwojem rynków, ale nie istnieją instytucje, które byłyby zdolne zastąpić państwo, które co prawda jest od nich mniej efektywne, lecz jako jedyne zabezpiecza relacje społeczne i stanowi ochronę przed fundamentalizmem rynkowym.

\section{$\star \star \star$}

Globalizacja w jej dotychczasowej formie stała się nośnikiem wartości, które w zasadzie mają zachodni i liberalny charakter, lecz są agresywnie promowane na arenie światowej jako wartości uniwersalne, których nieodłączna wartość powinna być oczywista dla wszystkich ludzi. Jednocześnie zachodnie wysiłki zmierzające do propagowania liberalnych idei spotykają się z szeregiem wtórnych reakcji przeciwko „imperializmowi wolności i praw człowieka oraz indywidualizmu". Potwierdzenie wagi wartości narodowych i lokalnych możemy dostrzec w poparciu dla różnego rodzaju fundamentalizmu przez społeczności $\mathrm{w}$ innych kulturach niż zachodnie. Takie niepokoje są chwytliwym narzędziem dla bardziej radykalnych grup politycznych, wzywających do zachowania tradycyjnych wartości oraz odrzucenia obcych wzorów. Chaos w różnych regionach świata wywołuje groźne skutki: wojny, uchodźcy, embarga, sankcje, radykalna ideologia i terroryzm powstają w następstwie upadłego porządku państwowego. Tutaj radykałowie znajdują rozwiązania obecnych problemów w protekcjonizmie i ksenofobii. Świat wielopłaszczyznowy - świat wielu aktorów różniących się kulturowo i politycznie, ale współzależnych gospodarczo - nie będzie w pełni bezkonfliktowy, a absolutny spokój jest iluzoryczny. To świat stający naprzeciw złożonych globalnych zagrożeń, wobec których władza i rola wielkich korporacji są kwestionowane przez niezliczoną liczbę instytucji. Kluczowe zadanie do wykonania polega zarówno na poszukiwaniu równowagi (musi się więc opierać na współpracy poszczególnych krajów i instytucji międzynarodowych), jak i na podejmowaniu działań w ustalaniu norm, które będą dotyczyć nowych transnarodowych kwestii. 


\section{Literatura}

Acharya, A. (2017). „After Liberal Hegemony: The Advent of a Multiplex World Order”. Ethics \& International, Affairs, 8 (September).

Ake, C. (1995). „The New World Order: A View from Africa”. W: H.-H. Holm, G. Sørensen (eds.). Whose World Order: Uneven Globalization and the End of the Cold War. Boulder: Westview.

Altman, R.C. (2009). „The Great Crash, 2008: A Geopolitical Setback for the West”. Foreign Affairs, 88 (1).

Arendt, H. (2007). Polityka jako obietnica. Warszawa: Prószyński i S-ka.

Birch, K. (2015). „Neoliberalism: The whys and wherefores ... and future directions”. Sociology Compass, 9 (7).

Centeno, M.A., Cohen, J.N. (2012). „The Arc of Neoliberalism”. Annual Review of Socio$\log y, 38$ (1), s. 317-340.

Charrad, M.M. (2006). „Waves of Comparative and Historical Sociology”. International Journal of Comparative Sociology, 47 (5), s. 355-356.

Cox, M. (2012). „Power Shifts, Economic Change and the Decline of the West?”. International Relation, 26 (4).

Duménil, G., Lévy, D. (2011). The Crisis of Neoliberalism. Cambridge: Harvard University Press.

Epstein, G.A. (2005). „Introduction”. W: G.A. Epstein (ed.). Financialization and the World Economy. Cheltenham-Northampton: Edward Elgar Publishing.

Foster, J.B., McChesney, R.W. (2014). Kryzys bez końca. Warszawa: Instytut Wydawniczy Książka i Prasa.

Friedman, G. (b.d.). The Crisis of the Middle Class and American Power, https://worldview. stratfor.com/article/crisis-middle-class-and-american-power (dostęp: 31.12.2013).

Giddens, A. (2014). Europa. Burzliwy i potężny kontynent, przeł. O. Siara. Warszawa: Wydawnictwo Naukowe PWN.

Golinowski, J. (2015). „Europa w obliczu kryzysu neoliberalnego paradygmatu rozwoju”. W: A. Wojtaszak (red.). Myśl polityczna w XX i XXI wieku. Wybrane zagadnienia. T. 1: Teoria - historia - współczesność. Szczecin: Wydawnictwo Naukowe Wydziału Humanistycznego US Minerwa, s. 87-109.

Golinowski, J. (2016). „Ekonomiczne przesłanki dychotomii pomiędzy Zachodem a Wschodem jako element pozycjonowania na mapie świata”. Transformacje. Pismo Interdyscyplinarne, 1-2.

Golinowski, J. (2017). „Współczesne archetypy polityki w obliczu kryzysu praktyk modernizacyjnych”. W: J. Nocoń (red.). Zagadnienia teorii polityki. Gdańsk: Wydawnictwo Uniwersytetu Gdańskiego.

Gray, J. (2001). „Ślad Oświecenia”. W: J. Gray. Po liberalizmie. Eseje wybrane, przeł. P. Maciejko, P. Rymarczyk. Warszawa: Fundacja Aletheia. 
Gray, J. (2014). Fałszywy świt. Urojenia globalnego kapitalizmu, przeł. M. Kotowski. Wrocław: Wydawnictwo „Wektory”.

Guillén, M.F. (2016). The Architecture of Collapse: The Global System in the $21^{\text {st }}$ Century. Oxford: Oxford University Press.

Guillén, M.F., Ontiveros, E. (2016). Global Turning Points. Cambridge: Cambridge University Press.

Jacobs, M., Mazzucato, M. (2016). Rethinking Capitalism: Economics and Policy for Sustainable and Inclusive Growth. New York: John Wiley \& Sons.

Janssen, T. (2016). A Love-Hate Relationship Far-right Parties and the European Union. Brussels: Rosa Luxemburg Stiftung.

Keohane, R.O. (1984). After Hegemony: Cooperation and Discord in the World Political Economy. Princeton: Princeton University Press.

Kissinger, H. (2014). „Henry Kissinger on the Assembly of a New World Order”. Wall Street Journal, August 29 ${ }^{\text {th }}$, www.wsj.com/articles/henry-kissinger-on-the-assembly-of-a-new-world-order-1409328075 (dostęp: 5.11.2017).

Klementewicz, T. (2013a). „Dekonspiracja globalnego Lewiatana. W poszukiwaniu paradygmatu badania neoliberalnej globalizacji”. Kwartalnik Naukowy OAP UW „e-Politikon”, 8, http://cejsh.icm.edu.pl/cejsh/element/bwmetal.element.cejsh-a0dab6c9-f508-421a-bc7b-f94b21f4dcc3 (dostęp: 5.11.2017).

Klementewicz, T. (2013b). Geopolityka zrównoważonego rozwoju. Ewolucja cywilizacji i państwa w trakcie dziejowo twórczych kryzysów. Warszawa: Dom Wydawniczy Elipsa.

Lindsey, B., Teles, S. (2017). The Captured Economy: How the Powerful Enrich Themselves, Slow Down Growth, and Increase Inequality. Oxford: Oxford University Press. Mazarr, M.J. (2017). „The Once and Future Order: What Comes after Hegemony?”. Foreign Affairs, 96 (1) (January/February).

Neilson, B., Mezzadra, S. (2014). „The State of Capitalist Globalization”. Viewpoint Magazin, 4 (September).

Nye, J.S. (2017). „Will the Liberal Order Survive? The History of an Idea”. Foreign Affairs, January/February Issue.

Peck, J. (2013). „Explaining (with) neoliberalism”. Territory, Politics, Governance, 1 (2), s. $132-157$.

Piketty, Th. (2015). Kapitał w XXI wieku, przeł. A. Bilik. Warszawa: Wydawnictwo Krytyki Politycznej.

Rajan, R.G. (2010). Fault Lines: How Hidden Fractures Still Threaten the World Economy. Princeton: Princeton University Press.

Rodrik, D. (2011). The Globalization Paradox: Democracy and the Future of the World Economy. New York-London: W.W. Norton \& Company.

Roubini, N. Mihm, S. (2011). Ekonomia kryzysu, przeł. R. Mitoraj. Warszawa: Oficyna a Wolters Kluwer business. 
Slaughter, A.M. (2017). „The Return of Anarchy?”. Journal of International Affairs, March $15^{\text {th }}$. Stiglitz, J.E. (2004). The Post-Washington Consensus. The Initiative for Pol, http://policydialogue.org/files/events/Stiglitz_Post_Washington_Consensus_Paper(dostęp: 5.11.2017).

Toporowski, J. (2012). Dlaczego gospodarka światowa potrzebuje krachu finansowego. Warszawa: Instytut Wydawniczy Książka i Prasa.

Venugopal, R. (2015). „Neoliberalism as concept”. Economy and Society, 44 (2), s. 165-187. Verick, S., Iyanatul, I. (2010). The Great Recession of 2008-2009: Causes, Consequences and Policy Responses, Discussion Paper No. 4934, Bonn: Institute for the Study of Labor.

Wagner, P. (2001). Theorizing Modernity: Inescapability and Attainability in Social Theo$r y$. London: Sage.

Williamson, J. (2004). The Washington Consensus as Policy Prescription for Development: Practitioners of Development, World Bank, January $13^{\text {th }}$.

\section{Streszczenie}

Prezentowany tekst dotyczy kryzysu praktyk modernizacyjnych, odnoszącego się do ram konstytutywnych ładu politycznego. Obecny kryzys dotyczy nie tylko sfery finansowej i produkcji, ale również sfery społecznej, politycznej oraz ideowo-moralnej. Jest to kryzys systemowy nie tyle kapitalizmu i nie tyle gospodarki rynkowej, ile ich dewiacji w postaci neoliberalizmu stanowiącego spekulatywne uzasadnienie dla ekonomii głównego nurtu. Zachodnia myśl ekonomiczna doprowadziła w konsekwencji do wirtualizacji gospodarki, która w wirtualnym obrocie ekonomicznym walorami, które nie istnieją - generuje zyski, w postaci pieniądza tworzonego przez banki w mechanizmie kreacji pieniądza z depozytów. Jest to prawdopodobnie największe zło, jakie obecnie przyczynia się do kryzysu Zachodu.

Słowa kluczowe: kryzys, ekonomia głównego nurtu, promocja wartości zachodnich, wolny rynek, prywatyzacja, transnarodowe korporacje 